\title{
PENGARUH PERSEPSI WAJIB PAJAK TENTANG PENERAPAN PP NO 23 \\ TAHUN 2018, PEMAHAMAN PERPAJAKAN DAN SANKSI PERPAJAKAN TERHADAP KEPATUHAN WAJIB PAJAK UMKM DIMAKASASAR
}

Carolus Askikarno Palalangan, Ribka Pakendek, Luther P. Tangdialla, Universitas Kristen Indonesia Paulus Makassar carolusaskikarno@gmail.com

\begin{abstract}
ABSTRAK
Penelitian ini bertujuan untuk mengetahui Pengaruh: (1) Penerapan PP No. 23 tahun 2018 wajib pajak terhadap Kepatuhan Wajib Pajak UMKM, (2) Pemahaman Perpajakan terhadap Kepatuhan Wajib Pajak UMKM, dan (3) Sanksi Perpajakan terhadap Kepatuhan Wajib Pajak UMKM, serta (4) Penerapan PP No. 23 Tahun 2018, Pemahaman Perpajakan, dan Sanksi Perpajakan secara bersama-sama terhadap Kepatuhan Wajib Pajak Usaha Mikro, Kecil, dan Menengah (UMKM) di Kota Makassar. Populasi dalam penelitian ini adalah Wajib Pajak UMKM yang terdaftar di KPP Pratama Makassar. Sampel dalam penelitian ini 50 wajib pajak. Metode pengumpulan data dengan kuesioner. Uji prasyarat analisis meliputi uji normalitas, uji linieritas, uji heteroskedastisitas, dan uji multikolinieritas. Teknik analisis data yang digunakan adalah regresi linier berganda. Hasil penelitian ini menunjukkan penerapan PP No. 23 tahun 2018 wajib pajak berpengaruh positif dan signifikan terhadap kepatuhan wajib pajak UMKM. Hal tersebut dibuktikan nilai koefisien regresi bernilai positif yaitu 0,408 dan t hitung lebih besar jika dibandingkan dengan $t$ tabel $(3,511>2,01290)$ pada signifikansi $0,001<5 \%$. Pemahaman perpajakan berpengaruh positif dan signifikan terhadap kepatuhan wajib pajak UMKM. Hal tersebut dibuktikan nilai koefisien regresi bernilai positif yaitu 0,215 dan $t$ hitung lebih besar jika dibandingkan dengan $t$ tabel $(2,079>2,01290)$ pada signifikansi $0,043<5 \%$. Sanksi perpajakan berpengaruh positif dan signifikan terhadap kepatuhan wajib pajak UMKM. Hal tersebut dibuktikan nilai koefisien regresi bernilai positif yaitu 0,297 dan $\mathrm{t}$ hitung lebih besar jika dibandingkan dengan $(2,468>2,01290)$ pada signifikansi 0,017<5\%. penerapan PP No. 23 tahun 2018 wajib pajak, pemahaman perpajakan, dan sanksi perpajakan berpengaruh positif dan signifikan secara bersama-sama terhadap kepatuhan wajib pajak UMKM. Hal tersebut dibuktikan dengan nilai signifikansi yaitu $0,000<5 \%$ dan nilai $\mathrm{F}$ hitung lebih besar jika dibandingkan dengan $\mathrm{F}$ tabel $(13,270>$ 2,80) pada signifikansi $0,000<5 \%$.
\end{abstract}

Kata Kunci: Kepatuhan Wajib Pajak, Penerapan PP No. 23 Tahun 2018, Pemahaman Perpajakan, Sanksi Perpajakan

\section{ABSTRACT}

The purpose of this study was to determine the influence of: (1) Implementation Of PP No. 23 Tahun 2018 for tax compliance of MSMEs, (2) the understanding of taxation for tax compliance of MSMEs, (3) Ttax penalties for tax compliance of MSMEs, and also (4) Implementation Of PP No. 23 Tahun 2018 And The Understanding Of Taxation And Tax Penalties together on Tax Compliance of MSMEs. The population in this study is the MSMEs 
in the city of Makassar. The samples in this research are taking from 50 MSMEs. The data collecting method is by giving questionnaire. Analysis prerequisite test included normality test, linearity test, heteroscedasticity test, and multicolinearity test. The data analysis technique used a simple and multiple linear regression analysis. The result of the research shows Implementation Of PP No. 23 Tahun 2018 positively influance and the significance towards the tax compliance. It is proved that the regression coefficient is positive 0,408 and $t$ count is greater compared to t table $(3,511>2,01290)$ in the significance of $0,001<5 \%$. The understanding of taxation positively influence and significant toward the tax compliance. It is proved that the the regression coefficient is positive 0,215 and t count is greater compared to t table (2,079>2,01290) in the significance of 0,043<5\%. Tax penalties positively influence and significant toward the tax compliance. It is proved that the regression coefficient is positive 0,297 and $t$ count is greater compared to $t$ table $(2,468>2,01290)$ in the significance of 0,017 < 5\%. Implementation Of PP No. 23 Tahun 2018, the understanding taxation and taxpenalties positively together influenced toward the tax compliance. It is proved that the significance of 0,000<5\% and $F$ count is greater compared to $F$ table $(13,270>2,80)$ in the significance of $0,000<5 \%$.

Keywords: Tax Compliance, Implementation Of PP No. 23 Tahun 2018, The Understanding of Taxation, Tax Penalties.

\section{PENDAHULUAN}

Pajak merupakan hal yang sangat penting bagi tiap negara. Semakin banyak orang yang membayar pajak, maka semakin banyak pula fasilitas dan berbagai infrastruktur yang dibangun. Oleh karena itu, pajak adalah ujung tombak pembangunan. Penerimaan pajak terdiri atas penerimaan pajak langsung dan tidak langsung. Dari tahun ke tahun besarnya pendapatan negara dari sektor perpajakan ditargetkan terus meningkat sehingga diperlukan pula usaha yang lebih untuk mencapainya.

Negara Indonesia menganut sistem pemungutan pajak self assessment. Self assessment system merupakan suatu sistem pemungutan pajak dimana wewenang untuk menentukan besarnya pajak yang harus dibayar oleh wajib pajak terletak pada pihak wajib pajak yang bersangkutan.Dalam sistem ini wajib pajak sifat aktif untuk menghitung, menyetor serta melaporkan pajaknya sendiri kepada Kantor Pelayanan Pajak ( KPP ), sedangkan fiskus hanya memberi penerangan atau sebagai pengawas pajak tersebut.

Pemahaman perpajakan diperlukan untuk memudahkan wajib pajak dalam mematuhi kewajiban perpajakannya. Pemahaman perpajakan meliputi perhitungan pajak, penyetoran pajak, pelaporan pajak, dan pengisian SPT. Semua itu dapat dilakukan oleh wajib pajak secara mudah jika wajib pajak memiliki pemahaman tentang perpajakan yang berlaku. Rahadi (2014) menyatakan bahwa pengetahuan dan pemahaman pajak berpengaruh positif terhadap kepatuhan wajib pajak. Pemahaman Wajib Pajak tentang peraturan perpajakan merupakan penyebab internal karena berada di bawah kendali wajib pajak sendiri. Tingkat pengetahuan dan pemahaman Wajib Pajak yang berbeda-beda akan mempengaruhi penilaian masing-masing Wajib Pajak untuk berperilaku patuh dalam melaksanakan kewajiban 
perpajakan. Tingkat pemahaman Wajib Pajak tinggi akan membuat Wajib Pajak memilih berperilaku patuh dalam melaksanakan kewajiban perpajakan.

Menurut Tjahjono (2005), sanksi pajak adalah suatu tindakan yang diberikan kepada Wajib Pajak ataupun pejabat yang berhubungan dengan pajak yang melakukan pelanggaran baik secara sengaja maupun karena alpa. Sanksi perpajakan merupakan jaminan bahwa ketentuan peraturan perundang-undangan perpajakan akan dipatuhi. Dengan kata lain, sanksi perpajakan merupakan alat pencegah agar wajib pajak tidak melanggar norma perpajakan.

Dirjen Pajak telah menetapkan beberapa kebijakan untuk meningkatkan penerimaan pajak. Kebijakan ataupun peraturan tersebut diharapkan dapat meningkatkan kepatuhan wajib pajak. Saat ini pemerintah mulai melirik sektor swatsa yang dipastikan memiliki potensi besar untuk pemasukan pajak. Sektor tersebut adalah Usaha Mikro, Kecil, dan Menengah (UMKM). Antisipasi pemerintah untuk terus memaksimalkan pengupayaan pendapatan dari sektor perpajakan dikembangkan melalui penerbitan peraturan perhitungan pajak terutang dengan sederhana melalui Peraturan Pemerintah Nomor 23 tahun 2018 tetang Pajak Final 0,5\% untuk Wajib Pajak dengan peredaran bruto tertentu atau lebih umum disebut PP No. 23 Tahun 2018.

Kegiatan usaha mikro, kecil, dan menengah (UMKM) merupakan salah satu bidang usaha yang dapat berkembang dan konsisten dalam perekonomian nasional. UMKM menjadi wadah yang baik bagi penciptaan lapangan pekerjaan yang produktif.

Penelitian ini di lakukan di Makassar dengan pertimbangan bahwa banyak UMKM di Makassar memiliki pengetahuan tentang pajak yang masih kurang, masih banyak wajib pajak yang melanggar karena di anggap pelaporan yang masih sulit dan merepotkan

Berdasarkan uraian diatas maka penulis ingin mengetahui Pengaruh Penerapan PP No 23. Tahun 2018 wajib pajak, Pemahaman Perpajakan Dan Sanksi Perpajakan Terhadap Kepatuhan Wajib Pajak Usaha Mikro, Kecil Dan Menengah Di Makassar.

\section{TINJAUAN PUSTAKA}

Pajak merupakan suatu sumber dana pemerintah untuk melakukan pembangunan, baik di pemerintah pusat maupun tingkat derah yang sudah diatur undang-undang. Pajak diperoleh dari pungutan wajib yang dibayar oleh rakyat untuk negara yang tujuannya untuk mengelola pemerintah dan masyarakat umum

Menurut sommerfeld Ray M, Anderson Herschel M, Brock Horace R Pajak adalah suatu pengalihan sumber dari bagian swasta ke bagian pemerintah yang bukan karena pelanggaran hukum namun wajib untuk dilaksanakan. Hal ini berdasarkan peraturan yang telah ditentukan dan tanpa memperoleh imbalan secara proporsional dan langsung, agar pemerintah bisa menjalankan dan melaksanakan tugasnya dengan baik.

Dalam pengertian pajak terdapat unsur-unsur pajak, antara lain sebagai berikut.

1. Iuran pajak harus berlandaskan peraturan Undang-Undang dan peraturan pengerjaannya.

2. Pajak digunakan untuk keperluan pengeluaran umum pemerintah (pengeluaran rumah tangga negara) dalam menjalankan serta menyelesaikan fungsi pemerintahan.

3. Tidak diperbolehkan kontraprestasi atau imbalan dari individual oleh pemerintah.

4. Sifat pajak bisa dipaksakan, dimana dikarenakan pada suatu kondisi, kejadian, keadaan dan perbuatan yang memberikan suatu kedudukan tertentu kepada seseorang. 
5. Pajak dilakukan oleh negara (baik pemerintah daerah maupun pemerintah pusat)

\section{Kepatuhan Wajib Pajak}

\section{a. Kepatuhan}

Kepatuhan merupakan keadaan dimana seseorang taat dan tidak menyimpang dari suatu aturan. Rahmat saleh (2004:2) menyatakan bahwa teori kepatuhan secara signifikan diteliti melalui kajian ilmu social khususnya di bidang psikolog dan sosiologi dimana kedua ilmu tersebut lebih menekankan pada pentingnya proses sosialisasi dalam mempengaruhi perilaku kepatuhan individu

\section{b. Wajib Pajak}

Pajak merupakan salah satu sumber Negara yang diperoleh secara langsung dari pembayaran wajib pajak masyarakat digunakan untuk membiayai pembangunan Negara. Dalam Mardiasmo (2011:1) Rochmat Soemitro mendefenisikan pajak sebagai iuran rakyat kepada Negara yang didasarkan pada undang-undang serta dapat dipaksakan tampat mendapatkan timbal balik secara langsung. Tujuan pajak adalah untuk membiayai pembangunan.

Wajib Pajak merupakan orang pribadi atau badan yang mempunyai hak dan kewajiban., meliputi pembayar pajak, pemungut pajak, pemotong pajak, yang diatur dalam perundang-undangan perpajakan. Wajib Pajak bukan hanya bagi orang yang sudah memiliki Nomor Pokok Wajib Pajak (NPWP) saja, namun juga bagi yang sudah memenuhi persyaratan sebagai wajib pajak meskipun belum memiliki NPWP.

\section{c. Kepatuhan Wajib Pajak}

Menurut Kamus Besar Bahasa Indonesia, istilah kepatuhan berarti tunduk atau patuh pada ajaran atau aturan. Aturan yang berlaku dalam perpajakan adalah Undang-Undang Perpajakan. Kepatuhan wajib pajak dapat diartikan sebagai keadaan dimana wajib pajak taat dalam melaksanakan kewajiban perpajakannya atau tidak menyimpang dari peraturan perpajakan yang berlaku. Kepatuhan merupakan keadaan dimana seseorang taat dan tidak menyimpang dari suatu aturan (Fatmawati 2015). Peraturan Menteri Keuangan Republik Indonesia Nomor 192/PMK.03/2007 Pasal 1 menyebutkan bahwa wajib pajak patuh adalah wajib pajak yang memenuhi persyaratan sebagai berikut:

1. Tepat Waktu dalam menyampaikan Surat Pemberitahuan;

2. Tidak mempunyai tunggakan pajak untuk semua jenis pajak, kecuali tunggakan pajak yang telah memperoleh izin mengangsur atau menunda pembayaran pajak dan tidak termasuk utang pajak yang belum melewati batas akhir pelunasan;

3. Laporan keuangan diaudit oleh Akuntan Publik atau lembaga pengawasan keuangan pemerintah dengan pendapat Wajar Tanpa Pengecualian

4. Tidak pernah dipidana karena melakukan tindak pidana di bidang perpajakan berdasarkan putusan pengadilan yang telah mempunyai kekuatan hukum tetap dalam jangka waktu 5 (lima) tahun terakhir.

Norman D. Nowak dalam Sony Devano (2006: 110) menggambarkan

kepatuhan dan kesadaran pemenuhan kewajiban perpajakan sebagai sebuah "iklim" yang tercemin dalam situasi berikut: 
1) Wajib pajak paham dan berusaha memhami ketentuan peraturan perundang undangan perpajakan.

2) Wajib pajak mengisi formulir pajak dengan lengkap dan jelas.

3) Wajib pajak menghitung jumlah pajak yang terutang dengan benar.

4) Wajib pajak membayar pajak yang terutang tepat pada waktunya.

Berdasarkan penjelasan beberapa pengertian kepatuhan wajib pajak, maka penulis dapat menyimpulkan bahwa kepatuhan wajib pajak merupakan suatu sikap wajib pajak mematuhi peraturan yang berlaku dalam memenuhi kewajiban perpajakannya.

\section{d. Faktor-faktor yang Mempengaruhi Kepatuhan Wajib Pajak}

Kepatuhan wajib pajak dapat dipengaruhi oleh dua faktor. Faktor tersebut adalah faktor internal dan eksternal. Faktor internal merupakan faktor yang berasal dari diri wajib pajak sendiri dan berhubungan dengan karakteristik individu yang dapat menjadi pemicu dalam menjalankan kewajiban perpajakannya. Faktor eksternal adalah faktor luar diri wajib pajak, seperti situasi dan lingkungan sekitar wajib pajak. Chaizi Nasucha (2004: 9) menggolongkan Wajib Pajak patuh jika Wajib Pajak yang bersangkutan mendaftarkan diri, menghitung, menyetor pajak terutang, dan melaporkan pajak melalui penyampaian SPT dengan benar dan tepat waktu.

\section{Pengertian Persepsi wajib pajak tentang Penerapan PP No. 23 Tahun 2018 a. Pengertian Persepsi Wajib Pajak}

Hammer dan Organ dalam Indrawijaya (2010) menyatakan bahwa persepsi adalah "the process by which people organize, interpret, experience, and process cues or material (inputs) received from the external environment". Persepsi yang dimaksud oleh Hammer dan Organ tersebut adalah sebuah proses dimana seseorang mengorganisasi, menginterpretasi, mengalami, dan mengolah isyarat atau materi yang diterima dari lingkungan luar.

Arfan Ikhsan Lubis (2011: 93) berpendapat bahwa persepsi merupakan cara bagaimana individu menginterpretasikan atau memandang peristiwa, objek, serta manusia dalam suatu gambaran yang berarti. Artinya, persepsi berkorelasi positif terhadap daya tangkap masing-masing individu. Persepsi menggambarkan cara pandang seseorang terhadap suatu rangsangan yang diperolehnya. Arfan Ikhsan Lubis menjelaskan bahwa persepsi bukan ditentukan oleh jenis atau bentuk rangsangan tetapi lebih dipengaruhi oleh karakteristik individu yang merespon rangsangan tersebut.

\section{b. Pengertian Penerapan PP No. 46 Tahun 2013}

Dalam Kamus Besar Bahasa Indonesia, penerapan atau pelaksanaan sama dengan implementasi. Sedangkan menurut Airu dalam Burhan(2015) implementasi merupakan suatu kegiatan atau usaha yang dilakukan oleh pelaksana kebijakan dengan harapan akan memperoleh hasil yang sesuai dengan tujuan atau sasaran dari kebijakan itu sendiri.

Penghasilan yang diatur dalam Peraturan Pemerintah (PP) Nomor 23 Tahun 2018, merupakan kebijakan Pemerintah yang mengatur mengenai Pajak Penghasilan atas penghasilan dari usaha yang diterima atau diperoleh wajib pajak yang memiliki peredaran bruto tertentu (Direktorat Jenderal Pajak, 2018). Peraturan Pemerintah Republik Indonesia Nomor 23 Tahun 2018 tentang Pajak Penghasilan atas Penghasilan dari Usaha yang Diterima atau Diperoleh Wajib Pajak yang memiliki Peredaran Bruto Tertentu atau biasa disebut PP 
No. 23 Tahun 2018 merupakan kebijakan perpajakan yang tergolong baru. Peraturan ini mulai berlaku sejak diterbitkan pada 1 Juli 2018 Tujuan penerbitan peraturan ini adalah untuk memberikan kemudahan kepada Wajib Pajak orang pribadi dan badan yang memiliki peredaran bruto tertentu dalam melaksanakan kewajiban pajaknya. Oleh karena itu pemerintah memberikan perlakuan tersendiri terkait ketentuan mengenai penghitungan, penyetoran, dan pelaporan Pajak Penghasilan yang terutang.

Tujuan pemerintah memberlakukan PP ini adalah (kusbiantoro 2013)

1. Memberikan kemudahan dan penyederhananaan aturan perpajakan

2. Mengedukasi wajib pajak untuk terlibat administrasi

3. Meningkatkan pengetahuan tentang manfaat perpajakan bagi wajib pajak

Berdasarkan uraian yang telah disebutkan diatas, penelitian ini mengukur penerapan PP No. 23 tahun 2018 menggunakan indikator sebagai berikut:

1. Pengetahuan Wajib Pajak terkait ketentuan umum PP No. 23 Tahun 2018 yang meliputi pemberlakuan peraturan dan isi peraturan (objek dan subjek yang dikenai peraturan).

2. Sikap Wajib Pajak terhadap tujuan yang telah ditetapkan oleh pemerintah dengan adanya penerapan PP No. 23 Tahun 2018

3. Kemampuan wajib pajak secara teknis berkaitan dengan PP No. 23 Tahun 2018 baik dalam tata cara perhitungannya maupun dalam pelunasannya.

\section{Pemahaman Perpajakan}

Pemahaman merupakan hal sangat penting dalam hal pajak pemahaman itu sendiri merupakan dimana seorang individu mengerti dan paham tentang sesuatu hal Seorang individu akan cenderung melakukan atau menyelesaikan suatu pekerjaan dengan caranya masing-masing sesuai dengan pengetahuan yang dimiliki. Ini berarti bahwa orang yang sudah memmiliki pemahaman mampu menerangkan kembali tentang suatu hal yang dia sudah pahami dengan baik.

Pemahaman perpajakan merupakan segala sesuatu tentang pajak yang sudah di pahami dan di mengerti dengan baik oleh wajib pajak dan wajib pajak tersebeut mampu menerangkan kembali kepada orang lain tentang perpajakan yang dia sudah menegrti dan pahami dengan baik. Scholes dan wolfson (1992) dalam Sri (2014) ia mengemukakan bahwa tingkat pemahaman dari wajib pajak dan fiskus mengenai undang-undang perpajakan memiliki pengaruh terhadap kepatuhan wajib pajak dalam menjalankan kewajiban perpajakannya. Ini berarti bahwa Wajib Pajak yang memahami peraturan perpajakan dengan baik akan lebih mampu melaksanakan kewajiban perpajakannya dibandingkan dengan Wajib Pajak yang tidak paham peraturan. Dengan tingginya tingkat pemahaman masyarakat terkait peraturan dan kebijakan perpajakan akan lebih mendorong kepatuhan Wajib Pajak dalam memenuhi kewajibannya secara sukarela tampa adanya paksasaan dari pihak tertentu Fidel (2010: 23) berpendapat bahwa seorang individu akan kesulitan dalam mempelajari bidang perpajakan jika tidak mempunyai pemahaman mendasar terkait dengan pajak melalui konsepkonsep dasar perpajakan. Pengetahuan tentang pajak dan kompleksitas pajak dipandang sebagai faktor yang berkontribusi terhadap sikap ketidakpatuhan pada Wajib Pajak (Prasasti, 2017). 
Pemahaman perpajakan sangat penting untuk wajib pajak karena dengan adanya pemahaman ini wajib pajak cenderung akan patu dan taat pada peraturan yang berlaku dan itu akan berpengaruh besar pada pendapatan sebuah Negara. Semakin tinggi pemahaman tentang pajak maka semakin kecil kemungkinan bagi wajib pajak untuk melanggar peraturan.

Nana Sudjana (2010: 24) membagi tingkatan Pemahaman perpajakan kedalam tiga kategori sebagai berikut:

1) Tingkat terendah adalah pemahaman terjemahan, mulai dari menerjemahkan dalam arti yang sebenarnya, mengartikan prinsip-prinsip,

2) Tingkat kedua adalah pemahaman penafsiran, yaitu menghubungkan bagian-bagian terendah dengan yang diketahui berikutnya, atau menghubungkan dengan kejadian, membedakan yang pokok dengan yang bukan pokok, dan

3) Tingkat ketiga merupakan tingkat tertinggi yaitu pemahaman ektrapolasi. Memiliki pemahaman tingkat ektrapolasi berarti seseorang mampu melihat dibalik yang tertulis, dapat membuat estimasi, prediksi berdasarkan pada pengertian dan kondisi yang diterangkan dalam ide-ide atau simbol, serta kemampuan membuat kesimpulan yang dihubungkan dengan implikasi dan konsekuensinya.

\section{Sanksi Perpajak}

\section{a. Pengertian Sanksi Perpajakan}

Sanksi adalah salah satu tindakan berupa tindakan yang diberikan kepada orang melanggar peratutran. Sanksi pajak merupakan hal yang sangat di hindari oleh wajib pajak. Sanksi pajak adalah hukuman negative yang diberikan kepada orang yang melanggar peraturan, Sedangkan denda adalah hukuman dengan cara membayar uang karena melanggar peraturan hukum yang berlaku (Aprilliana, 2017). Tapi, masih banyak orang wajib pajak yang terkena sanksi pajak karena mereka sering mengulang kesalahan yang sama saat mereka menyelesaikan kewajiban perpajakan. Pemerintah telah mempersiapakan rambu-rambu yang di atur dalam undang-undang perpajakan agar wajib pajak tidak melakukan kecurangan dalam menyelesaikan kewajibannya. jadi wajib pajak yang tidak menjalankan dengan baik kewajibannya atau melakukan kecurangan dalam hal membayar pajak akan mendapankan konsekuensi hukum karena semua ketentuan tentang pajak sudah di atur dalam undangundang. Menurut Alam (2014) Sanksi pajak juga diharapkan memberi efek jera bagi wajib pajak yang tidak patuh bayar pajak

Berdasarkan pendapat Mardiasmo (2011: 59) sanksi perpajakan merupakan jaminan bahwa ketentuan peraturan perundang-undangan perpajakan (norma perpajakan) akan dituruti/ditaati/dipatuhi

\section{HIPOTESIS}

H1: Persepsi wajib pajak Penerapan PP No. 23 tahun 2018, berpengaruh positif dan signifikan terhadap Kepatuhan Wajib Pajak UMKM

H2: Pemahaman Perpajakan berpengaruh positif dan signifikan terhadap Kepatuhan Wajib Pajak UMKM.

H3: Sanksi Perpajakan berpengaruh positif dan signifikan terhadap Kepatuhan Wajib Pajak UMKM. 
H4: Persepsi Wajib Pajak tetang Penerapan PP No. 23 Tahun 2018 wajib pajak, Pemahaman Perpajakan, dan Sanksi Perpajakan secara bersama-sama berpengaruh positif dan signifikan terhadap Kepatuhan Wajib Pajak UMKM

\section{METODE PENELITIAN}

Jenis data yang digunakan dalam penelitian ini adalah kuantitatif dan sumber data yang digunakan dalam penelitian ini adalah data primer dan data sekunder. Data primer merupakan data yang di peroleh secara langsung seperti hasil wawancara atau hasil pembagian kuisioner dengan tujuan tertentu sesuai dengan kebutuhan. Sedangkan data sekunder yang digunakan adalah di perlukan dalam penelitian ini sebagai pendukung sumber data sekunder yang digunakan berasal dari berbagai sumber informasi.

Metode yang digunakan adalah survey langsung dengan memberikan kuesioner kepada wajib pajak UMKM di Makassar dan untuk mendapatkan data melalui data wajib pajak UMKM yang terdaftar di KPP Pratama Makassar dan wawancara langsung kepada narasumber. Kuosoner yang di berikan berisi sejumlah pertanyaan yang harus di jawab oleh wajib pajak UMKM untuk mengukur kepatuhan wajib pajak di Makassar. Jumlah kuesoner yang di bagi berjumlah 50 dan jumlah kembali juga 50 Penelitian dilakukan dengan berbagai cara yaitu membagikan langsung kuesoner ke wajib pajak UMKM dengan mendatangi langsung tempat mereka membuka usaha, memberikan langsung kuesoner kepada wajib pajak di kantor KPP Pratama Makassar Utara, dan ada juga yang di berikan kepada dosen yang kebetulan bekerja di kantor KPP Pratama Makassar Utara.

Populasi merupakan wilayah generalisasi yang terdiri atas: obyek dan subyek yang mempunyai kualitas dan karakteristik tertentu yang ditetapakan oleh peneliti untuk mempelajari dan kemudian ditarik kesimpulannya. Populasi bukan hanya orang, tetapi juga obyek dan benda-benda alam yang lain. Populasi juga bukan sekedar jumlah yang ada pada obyek dan subyek yang dipelajari, tetapi meliputi seluruh karakteristik atau sifat yang dimiliki oleh subyek atau obyek tersebut (Sugiyono, 2013:119). Populasi dalam penelitian ini adalah seluruh wajib pajak UMKM yang Terdaftar di KPP Pratama Makassar Utara.

Sampel merupakan sebagian atau wakil populasi yang diteliti.Pengambilan sampel harus dipilih dengan seksama sehingga dapat mewakili (Suharsimi Arikunto, 2006: 131). Sampel merupakan bagian dari jumlah dan karakteristik yang dimiliki oleh populasi tersebut (Sugiyono, 2013:120) Teknik yang dipilih dalam penelitian ini menggunakan teknik purposive sampling yaitu teknik yang pengambilan sampel berdasarkan pertimbangan tertentu (Sugiyono, 2012: 68). Karakterisrik khusus yang menjadi pertimbangan dalam pengambilan sampel adalah pelaku UMKM dengan peredaran bruto kurang atau sama dengan Rp4,8 miliar pertahun. Jumlah sampel yang akan diambil dalam penelitian ini dihitung dari variabel penelitian (4), maka jumlah sampel minimalnya yaitu 10 × $4=40$. Dalam penelitian ini jumlah sampel yang digunakan sebanyak 50 responden.

\section{HASIL DAN PEMBAHASAN}

Data yang digunakan dalam penelitian ini merupakan data primer yang dikumpulkan melalui kuesioner yang dibagikan pada responden penelitian. Responden dalam penelitian ini adalah UMKM di Kota Makassar. Penelitian ini dilakukan pada bulan Desember 2018 
Sampai Januari 2019. Kuesioner yang disebarkan berjumlah 50 kuesioner untuk memenuhi sampel berdasarkan perhitungan dan semua kuesioner dapat digunakan. Penyebaran kuesioner dilakukan di daerah Tamalanrea, Biring Romang, dan dikantor KPP Pratama Makassar Pada saat menyebarkan kuesioner terkadang pemilik UMKM tidak berada di showroom sehingga peneliti akan mengambil data pada lain hari. Peneliti mengusahakan kuesioner diisi oleh pihak yang berwenang dan mengetahui tentang pajak yang digunakan untuk usahanya. Biasanya yang berwenang dalam urusan pajak adalah pemilik UMKM itu sendiri. Hal ini dilakukan agar pengisian kuesioner dapat maksimal dan hanya diisi oleh orang yang berwenang di UMKM tersebut. Kuesioner yang dibagikan yaitu 50 buah. Kuesioner tersebut dapat digunakan seluruhnya karena peneliti mengupayakan agar pemilik UMKM mengisi kuesioner dengan benar

\section{Uji Prasyarat Analisis}

\section{Hasil Uji Normalitas Data}

"Uji normalitas data bertujuan untuk menguji data dalam model regresi berdistribusi normal atau tidak normal" (Ghozali, 2011: 160).

Gambaran 1 Grafik Distribusinya Uji Normalitas

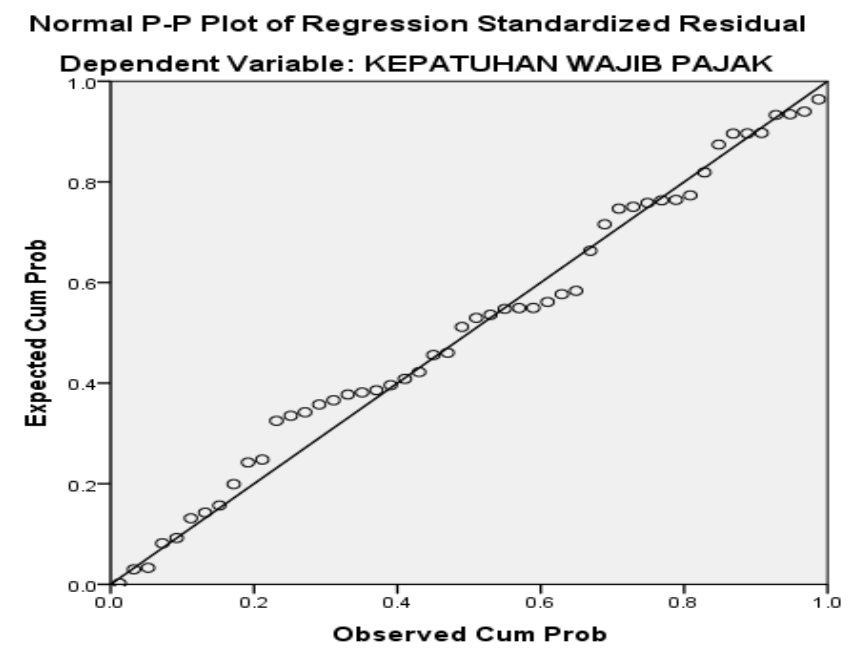

Dari gambar tersebut terlihat bahwa titik-titik data berada di dekat atau mengikuti garis dioagonalnya sehingga suda dipastikan bahwa data telah berdistribusi normal dan telah memenuhi syarat dalam analisis regresi linear berganda.

\section{Hasil Uji Linearitas}

Uji linearitas dilakukan untuk mengetahui hubungan antara variabel independen terhadap variabel dependen mempunyai hubungan yang linear secara signifikan atau tidak. Berikut ini hasil uji linearitas:

Tabel 1 Uji Linearitas

\begin{tabular}{|c|l|l|}
\hline Variabel & deviation from linearity & Keterangan \\
\hline $\mathrm{Y} * \mathrm{X} 1$ & 0,882 & Linear \\
\hline $\mathrm{Y} * \mathrm{X} 2$ & 0,862 & Linear \\
\hline $\mathrm{Y} * \mathrm{X} 3$ & 0,566 & Linear \\
\hline
\end{tabular}


Keseluruhan hasil tersebut dikatakan signifikan, sehingga dapat disimpulkan bahwa pengaruh masing-masing variabel independen terhadap variabel dependen bersifat linear.

\section{Uji Asumsi Klasik}

\section{Hasil Uji Heteroskedastisitas}

Uji heteroskedastisitas bertujuan untuk menguji dalam model regresi terjadi ketidaksamaan varian dari residual satu pengamatan ke pengamatan lain

Gambar 2. Hasil Kurva Scatterpot Untuk Kepatuhan Wajib Pajak(Y)

Scatterplot

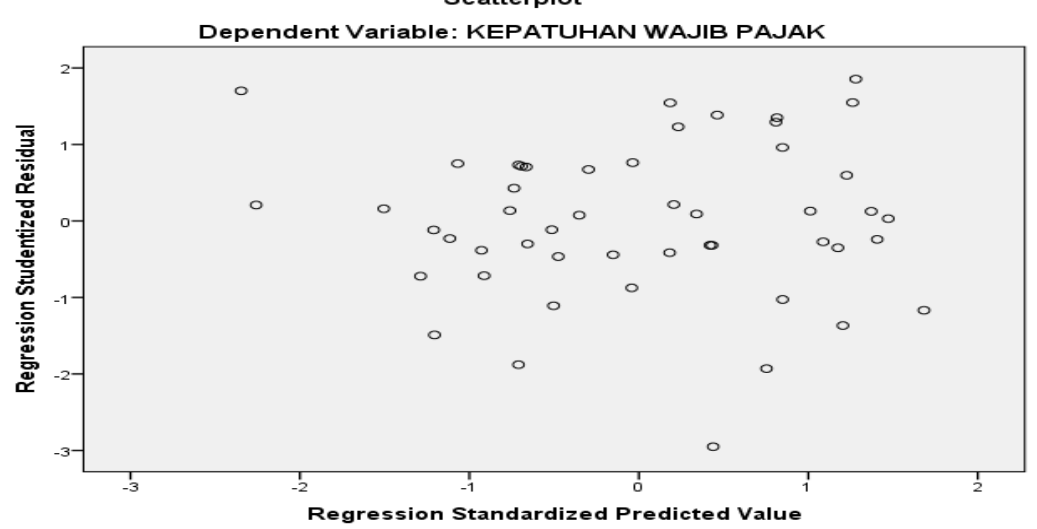

Berdasarkan Gambar diatas, dapat disimpulkan bahwa variabel bebas yang digunakan tidak terjadi heteroskedastisitas.

\section{Hasil Uji Multikolinearitas}

Uji multikolinieritas bertujuan untuk menguji dalam persamaan regresi ditemukan adanya korelasi antar variabel bebas (independence). Jika nilai Variance Inflation Factor (VIF) tidak lebih dari 10 dan nilai Tolerance tidak kurang dari 0,1 maka model dapat dikatakan terbebas dari multikolinearitas (Imam Ghozali, 2011:108). Hasil uji multikolinieritas dapat dilihat pada tabel berikut ini:

Tabel 2 Uji Multikolinearitas

\begin{tabular}{|c|c|c|c|}
\hline \multirow[b]{2}{*}{ Model } & \multicolumn{2}{|c|}{ Collinearity Statistics } & \multirow[b]{2}{*}{ Keterangan } \\
\hline & Tolerance & $V I P$ & \\
\hline $\begin{array}{l}\text { Penerapan PP No } \\
23 \text { Tahun } 2018\end{array}$ & 0,841 & 1,190 & $\begin{array}{l}\text { Tidak Terjadi } \\
\text { Multikolinearitas }\end{array}$ \\
\hline $\begin{array}{l}\text { Pemahaman } \\
\text { Perpajakan }\end{array}$ & 0,946 & 1,057 & $\begin{array}{c}\text { Tidak Terjadi } \\
\text { Multikolinearitas }\end{array}$ \\
\hline $\begin{array}{l}\text { Sanksi } \\
\text { Perpajakan }\end{array}$ & 0,836 & 1,197 & $\begin{array}{c}\text { Tidak Terjadi } \\
\text { Multikolinearitas }\end{array}$ \\
\hline
\end{tabular}

Sumber :data yang diolah 2019

Berdasarkan tabel di atas menunjukkan bahwa nilai VIF tiap variabel bebas lebih

kecil dari 10. Selain itu nilai tolerance lebih besar dari 0,1 sehingga dapat disimpulkan tidak terjadi multikolinieritas. 


\section{Uji Hipotesis}

\section{Hasil Uji Regresi Linear Berganda}

Analisis linear berganda bertujuan untuk mengetahui ada atau tidaknya pengaruh variable bebas terhadap variable terikat, uji t bertujuan untuk mengetahui ada atau tidaknya pengaruh parsial (sendiri) yang diberikan variable bebas $(\mathrm{X})$ terhadap variable terikat $(\mathrm{Y})$ sedangkan uji $\mathrm{f}$ bertujuan untuk mengetahui ada atau tidaknya pengaruh simultan (bersama-sama) yang di berikan variable bebas $(\mathrm{X})$ terhadap variable terikat $(\mathrm{Y})$ dan koefesien determinasi berfungsi untuk mengetahui berapa pesen pengaruh ang diberikan variable $(\mathrm{X})$ secara simultan terhadap variable $(\mathrm{Y})$.

\section{a. Uji t hitung}

Hipotesis dalam uji $\mathrm{t}$ adalah

a. H0 : Variabel bebas Tidak berpengaruh signifikan terhadap Variabel terikat

b. H1 : Variabel bebas berpengaruh signifikan terhadap Variabel terikat

Dasar pengambilan keputusan dalam uji T dalam analisis regresi yakni

a. H0 diterima dan $\mathrm{H} 1$ ditolak jika nilai $t$ hitung $<\mathrm{t}$ tabel atau jika nilai Sig. $>0,05$

b. H0 ditolak dan $\mathrm{H} 1$ diterima jika nilai thitung $>\mathrm{t}$ tabel atau jika nilai Sig. $>0,05$

$\mathrm{t}$ tabel $=\mathrm{t}(\alpha / 2 ; \mathrm{n}-\mathrm{k}-1)$

$\mathrm{t}$ tabel $=\mathrm{t}(0,025 ; 46)=2,012$

$\mathrm{n}=$ jumlah sampel

$\mathrm{k}=$ jumlah variable bebas

Tabel 3. Uji t hitung

Coefficients $^{\mathbf{a}}$

\begin{tabular}{|c|c|c|c|c|c|c|}
\hline \multirow{2}{*}{\multicolumn{2}{|c|}{ Model }} & \multicolumn{2}{|c|}{$\begin{array}{c}\text { Unstandardized } \\
\text { Coefficients } \\
\end{array}$} & \multirow{2}{*}{$\begin{array}{c}\begin{array}{c}\text { Standardized } \\
\text { Coefficients }\end{array} \\
\text { Beta }\end{array}$} & \multirow[t]{2}{*}{$\mathrm{T}$} & \multirow[t]{2}{*}{ Sig. } \\
\hline & & $\mathrm{B}$ & Std. Error & & & \\
\hline \multirow{4}{*}{1} & (Constant) & 9.815 & 5.472 & & 1.794 & .079 \\
\hline & $\begin{array}{l}\text { Penerapan PP No } 23 \\
\text { tahun } 2018\end{array}$ & .408 & .116 & .413 & 3.511 & .001 \\
\hline & Pemahamn perpajakan & .215 & .103 & .231 & 2.079 & .043 \\
\hline & Sanksi Perpajakan & .297 & .120 & .291 & 2.468 & .017 \\
\hline
\end{tabular}

a. Dependent Variable: Kepatuhan Wajib Pajak

\section{a. Uji Hipotesis Pertama}

Dari perhitungan pada tabel 4.13 nilai sig. untuk pengaruh $\mathrm{X} 1$ terhadap $\mathrm{Y}$ adalah sebesar 0,001<0,05 atau t hitung 3,511 > t tabel 2.012 maka dapat di simpulkan bahwa H0 ditolak H1 diterima terdapat pengaruh variable Penerapan PP No 23 Tahun 2018 (X1) terhadap Kepatuhan Wajib Pajak (Y).

b. Uji Hipotesis Kedua

Dari perhitungan pada tabel 4.13 nilai sig. untuk pengaruh $\mathrm{X} 2$ terhadap $\mathrm{Y}$ adalah sebesar 0,043<0,05 atau thitung 2,079> t tabel 2.012 maka dapat di simpulkan bahwa H0 ditolak H1 diterima. terdapat pengaruh variable Pemahaman Perpajakan (X2) Terhadap Kepatuhan Wajib Pajak (Y).

c. Uji Hipotesis ketiga 
Dari perhitungan pada tabel 4.13 nilai sig. untuk pengaruh $\mathrm{X} 3$ terhadap $\mathrm{Y}$ adalah sebesar0,017<0,05 atau thitung 2,468> t tabel 2.012 maka dapat di simpulkan bahwa H0 ditolak H1 diterima. terdapat pengaruh variable Sanksi Perpajakan (X3) Terhadap Kepatuhan Wajib Pajak (Y).

\section{b. Uji Nilai F}

Hipotesis dalam uji F adalah

a. H0 : Variabel bebas secara simultan Tidak berpengaruh signifikan terhadap Variabel terikat

b. H1 : Variabel bebas secara simultan berpengaruh signifikan terhadap Variabel terikat

Dasar pengambilan keputusan dalam uji dalam analisis regresi yakni

a. H0 diterima dan $\mathrm{H1}$ ditolak jika nilai $\mathrm{F}$ hitung < F tabel atau jika nilai Sig.>0,05

b. H0 ditolak dan $\mathrm{H} 1$ diterima jika nilai $\mathrm{F}$ hitung $>\mathrm{F}$ tabel atau jika nilai Sig. $<0,05$

$\mathrm{F}$ tabel $=(\mathrm{k} ; \mathrm{n}-\mathrm{k})$

F tabel $=(3 ; 47)=2,80$

Tabel 4. Uji $f$ tabel

ANOVA $^{\mathrm{a}}$

\begin{tabular}{|c|r|r|r|r|r|}
\hline Model & \multicolumn{1}{|c|}{$\begin{array}{c}\text { Sum of } \\
\text { Squares }\end{array}$} & \multicolumn{1}{|c|}{ Df } & \multicolumn{1}{c|}{$\begin{array}{c}\text { Mean } \\
\text { Square }\end{array}$} & F & Sig. \\
\hline Regression & 389.296 & 3 & 129.765 & 13.270 & $.000^{\mathrm{b}}$ \\
1 Residual & 449.824 & 46 & 9.779 & & \\
Total & 839.120 & 49 & & & \\
\hline
\end{tabular}

a. Dependent Variable: Kepatuhan Wajib Pajak

b. Predictors: (Constant), Sanksi Perpajakan, Pemahamn perpajakan,

Penerapan PP No 23 tahun 2018

Berdasarkan tabel diatas diketahui nilai signifikansi untuk pengaruh Penerapan PP No 23 Tahun 2018 (X1), Pemahaman Perpajakan (X2) dan Sanksi Perpajakan (X3) secara simultan Terhadap Kepatuhan Wajib Pajak (Y) adalah sebesar $0.000<0,05$ dan $\mathrm{f}$ hitung 13,270 >f tabel 2,27. Sehingga dapat disimpukan bahwa H1 diterima yang berarti terdapat pengaruh Penerapan PP No 23 Tahun 2018 (X1), Pemahaman Perpajakan (X2) dan Sanksi Perpajakan (X3) secara simultan Terhadap Kepatuhan Wajib Pajak (Y).

\section{c. Koefisien determinasi}

Koefisien determinasi digunakan untuk mengetahui seberapa besar hubungan dari beberapa variabel dalam pengertian yang lebih jelas. Koefisien determinasi akan menjelaskan seberapa besar perubahan atau variasi suatu variabel bisa dijelaskan oleh perubahan atau variasi pada variabel yang lain, berdasrkan hasil uji dengan SPSS diperoleh model summary 
Tabel

Koefisen
Model Summary

\begin{tabular}{|l|r|r|r|r|}
\hline $\begin{array}{l}\text { Mode } \\
1\end{array}$ & \multicolumn{1}{|c|}{$\mathrm{R}$} & R Square & $\begin{array}{c}\text { Adjusted R } \\
\text { Square }\end{array}$ & $\begin{array}{l}\text { Std. Error of } \\
\text { the Estimate }\end{array}$ \\
\hline 1 & $.681^{\mathrm{a}}$ & .464 & .429 & 3.127 \\
\hline
\end{tabular}

a. Predictors: (Constant), Sanksi Perpajakan, Pemahamn perpajakan, Penerapan PP No 23 tahun 2018

5. Uji

Determinasi

Dimana pada bagian ini terdapat nilai koefisien determinasi R-Square = 0,429(43\%). Ini menunjukkan bahwa sebesar $43 \%$ variasi variabel dependent (Y) yakni Kepatuhan Wajib Pajak dapat dijelaskan oleh 3 variabel independent Penerapan PP No 23 Tahun 2018 (X1), Pemahaman Perpajakan (X2) dan Sanksi Perpajakan (X3), artinya pengaruh variabel independen terhadap perubahan variabel dependen adalah $43 \%$, sedangkan sisanya sebesar $57 \%$ dipengaruhi oleh variabel lain selain variabel independen $\mathrm{X} 1, \mathrm{X} 2$ dan X3.

Berdasarkan Rumusan regresi berganda didapatkan persamaan untuk menentukan hubungan atau pengaruh Penerapan PP No 23 tahun 2018, Pemahaman Perpajakan dan Sanksi Perpajakan terhadap Kepatuhan Wajib Pajak.

$Y=9,815+0,408 X 1+0,215 X 2+0,297 X 3$

\section{KESIMPULAN DAN SARAN}

\section{Kesimpulan}

Berdasarkan hasil analisis, pembahasan hasil penelitian serta pengujian hipotesis yang dilakukan sebagaimana telah diuraikan sebelumnya, maka dapat disimpulkan sebagai berikut:

a) Variabel Kepatuhan Wajib Pajak merupakan Variabel terikat atau dinotasikan dengan simbol Y, Penerapan PP No 23 tahun 2018 (X1), Pemahaman Perpajakan sebagai variabel bebas (X2) dan Sanksi perpajakan juga masuk sebagai variabel bebas(X3). Pengambilan data dilakukan dengan membagikan kuisioner kepada 50 responden. Setelah dilakukan uji validitas dan uji reliabilitas didapatkan hasil bahwa semua pernyataan untuk masing masing variabel sudah valid dan reliabel atau dapat diandalkan sebagai alat ukur meskipun kuisioner tersebut digunakan berulang-ulang.

b) Berdasarkan uji hipotesis mulai dari uji parsial t diperoleh kesimpulan bahwa Penerapan PP No 23 tahun 2018 , Pemahaman Perpajakan dan Sanksi Perpajakan berpengaruh signifikan terhadap Kepatuhan Wajib Pajak, dari uji F disimpulkan bahwa Penerapan PP No 23 Tahun 2018, Pemahaman Perpajakan dan Sanksi Perpajakan secara simultan mempengaruhi Kepatuhan Wajib Pajak. Dari uji determinasi didapatkan angka r square sebesar 0,429 atau Penerapan Pp No 23 Tahun 2018, Pemahaman Perpajakan dan Sanksi Perpajakan secara bersamaan berpengaruh 43 persen terhadap Kepatuhan Wajib Pajak. 


\section{Saran}

Melihat terdapat pengaruh Penerapan PP No 23 Tahun 2018, Pemahman Perpajakan dan Sanksi Perpajakan Tehadap Kepatuhan Wajib Pajak maka disarankan pihak Pajak untuk melalukan sosialisasi perpajkan yang berlaku saat ini untuk meningkatkan pemahman wajib pajak supaya wajib pajak dapat memahami dan mengerti tentang perpajakan dan sanksi yang akan di terima wajib pajak jika melanggar.

\section{DAFTAR PUSTAKA}

Alam, Syamsu. (2014). "Pengaruh Sosialisasi Pajak, Kesadaran Wajib Pajak,

Dan Sanksi Pajak Terhadap Kepatuhan Wajib Pajak Dalam Membayar Pajak Bumi

Dan Bangunan Di Desa Baringeng Kecamatan Lilirilau Kabupaten Soppeng”. Skripsi

Fakultas Ekonomi dan Bisnis Islam: Universitas islam Negeri Alauddin Makassar.

Aprilliyana,Putri. (2017). “ Pengaruh Tarif Pajak, Kesadaran Dan Sanksi Perpajakan

Terhadap Kepatuhan Wajib Pajak Kendaraan Bermotor Studi Pada Wpop Samsat

Kota Surakarta”. Skripsi Fakultas Ekonomidan Bisnis Islam: Institut Agama Islam

Negeri Surakarta

Arikanto, Suharsimi.(2009). Dasar-Dasar Evaluasi Pendidikan (edisi revisi ). Jakarta Bumi Aksara

Burhan, Hana Pratiwi. (2015). "Pengaruh Sosialisasi Perpajakan, Pengetahuan Perpajakan, Persepsi Wajib Pajak Tentang Sanksi Pajak dan Implementasi PP No. 46 Tahun 2013 Terhadap Kepatuhan Wajib Pajak Orang Pribadi (Studi Empiris pada Wajib Pajak di Kabupaten Banjarnegara)".Skripsi.

Fakultas Ekonomika dan Bisnis: Universitas Diponegoro.

Fatmawati. (2015). Pengaruh Pemahaman Wajib Pajak Atas PP No. 46 Tahun 2013

Dan Implementasi Self Assessment System Terhadap Kepatuhan Wajib Pajak

Dengan Persepsi Wajib Pajak Sebagai Variabel Moderasi (Studi Empiris Pada

Pelaku UMKM Kerajinan Gerabah Kasongan) Skripsi Fakultas Ekonomi: Universitas Negeri Yogjakarta.

Fidel. (2010). Cara Mudah dan Praktis Memahami Masalah-Masalah Perpajakan.

Jakarta: Muara Kencana.

Ghozali, Imam. (2011) Aplikasi Analisis Multivariate denga Program IBM SPSS

19.Edisi ke 5. Semarang: Badan Penerbit Universitas Diponegoro

Mardiasmo. (2003). Perpajakan. Yogyakarta : Andi offset

Mardiasmo. (2011) Perpajakan Edisi Revisi. Yogyakarta: Andi.

Nasucha, Chaizi (2004). Reformasi Administrasi Publik: Teori dan Praktek.

Jakarta: PT Gramedia Widiasarana Indonesia.

Priambodo, Putut. (2017). "Pengaruh Pemahaman Peraturan Pajak, Sanksi Perpajakan,

Dan Kesadaran Wajib Pajak, Terhadap Kepatuhan Wajib Pajak Orang Pribadi Di Kantor Pelayanan Pajak Pratama Kabupaten Purworejo Pada Tahun 2017." Skripsi

Fakultas Ekonomi: Universitas Negeri Yogyakarta.

Peraturan Menteri Keuangan Republik Indonesia Nomor 192/PMK.03/2007 Pasal 1 
Tentang Kepatuhan Wajib Pajak.

Prasasti, Ria.(2017). "Pengaruh Pengetahuan Tentang Pajak, Sanksi Pajak, Dan

Pemeriksaan Pajak Terhadap Kepatuhan Wajib Pajak Di Kantor Wilayah

Direktorat Jenderal Pajak Daerah Istimewa Yogyakarta Tahun 2016". Skripsi Fakultas

Ekonomi: Universitas Negeri Yogyakarta.

Resyniar, Gandhys.(2013). "Persepsi Pelaku Usaha Mikro, Kecil, dan Menengah

(UMKM) terhadap Penerapan PP. 46 Tahun 2013”. Skripsi

dipublikasikan Malang: Universitas Brawijaya

Saleh, Rahmat.(2004). Studi Empiris Ketepatan Waktu Pelaporan Keuangan Perusahaan

Manufaktur di Bursa Efek Jakarta. Prosiding Simposium Nasional Akuntansi VII. Denpasar

Sudjana, Nana. (2010). Evaluasi Proses dan Hasil Pembelajaran. Jakarta: Bumi Aksara

Sugiyono. (2007). Metodologi Penelitian Bisnis. Bandung: CV. Alfabeta

Sugiyono. (2011). Metodologi Penelitian Kombinasi. Bandung: CV. Alfabeta

Sugiyono. (2012). Statistika untuk Penelitian. Bandung: CV. Alfabeta 